\title{
Expanded polytetrafluoroethylene in canine bile duct injury. A critical analysis ${ }^{1}$
}

\author{
Politetrafluoroetileno expandido na lesão do ducto biliar em cães. \\ Uma análise crítica
}

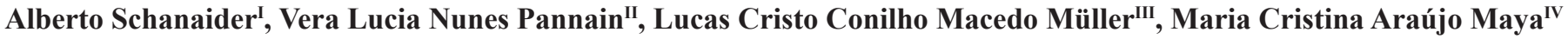

${ }^{1}$ Research performed at Center of Experimental Surgery and Postgraduate Program, Department of Surgery, Faculty of Medicine, Federal University of Rio de Janeiro (UFRJ), Brazil.

${ }^{\mathrm{I}}$ Full Professor, Head of the Center of Experimental Surgery and Coordinator of Postgraduate Program in Surgical Sciences, Department of Surgery, Faculty of Medicine, UFRJ, Rio de Janeiro, Brazil. CNPq and FAPERJ researcher. Responsible for conception of the scientific content with supervision of all phases of the study, manuscript writing and critical revision.

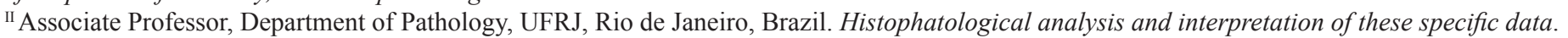

III Graduate student, Faculty of Medicine, UFRJ, Rio de Janeiro, Brazil. Helped with technical procedures and collection of study informations.

${ }^{\text {IV }}$ Associate Professor, Department of Surgery, State University of Rio de Janeiro, Brazil. Conception, design of the content of the study. Involved in technical procedures and with the analysis and interpretation of data. Manuscript writing.
\end{abstract}

\begin{abstract}
Purpose: Analyze the morphological and structural outcomes of a patch of expanded polytetrafluoroethylene in the treatment of an iatrogenic injury of the common bile duct. Methods: In Group 1 (Sham), 7 dogs underwent 3 laparotomies with intervals of 30 days between them. In Group 2, 10 dogs underwent transient common bile duct obstruction. After 30 days, this biliary occlusion was undone and a patch of expanded polytetrafluoroethylene replaced a fragment removed from the duct's wall. Thirty days after this last surgery, cholangiographic assessment of prosthesis patency and macro and microscopic evaluation of the biliary tract were performed. Daily clinical inspection completed the study outcomes. The Wilcoxon non-parametric test was used for statistical analysis. Results: In all dogs enlargement of the biliary tree diameter was observed 30 and 60 days after the first surgical procedure. Partial adhesion of the patch to the common bile duct as a free luminal foreign body was found in 6 dogs. The prosthesis was completely integrated to surrounding tissue in the remaining four. Conclusion: Although a feasible option for the treatment of biliary duct iatrogenic lesions, the expanded polytetrafluoroethylene prosthesis must be used with caution considering the potential risks for complications.
\end{abstract}

Key words: Bile Ducts. Polytetrafluoroethylene. Protheses and Implants. Dogs.

\section{RESUMO}

Objetivo: Analisar, evolutivamente, a morfologia e a estrutura de um fragmento de politetrafluoretileno expandido utilizado no tratamento de uma lesão iatrogênica do ducto biliar comum. Métodos: No grupo 1 (Simulação), sete cães foram submetidos a três laparotomias com intervalos de 30 dias entre elas. No grupo 2, em dez cães realizou-se uma obstrução tansitória do ducto biliar comum. Após 30 dias, a oclusão biliar foi desfeita e um fragmento da parede ductal foi substituído por um retalho de politetrafluoretileno expandido. Trinta dias após esta última operação, foram efetuadas uma avaliação colangiográfica da perviedade da prótese e uma análise macro e microscópica do trato biliar. Inspeções clínicas diárias completaram o estudo evolutivo. O teste não paramétrico de Wilcoxon foi utilizado para análises estatísticas. Resultados: Decorridos 30 e 60 dias do primeiro procedimento cirúrgico, observou-se, em todos os cães, aumento do diâmetro da árvore biliar. Em seis cães verificou-se a presença do fragmento da prótese parcialmente aderido à parede do ducto biliar comum e também solta no lúmen da via biliar. A prótese estava completamente integrada aos tecidos circunvizinho nos demais quarto animais. Conclusão: A prótese de politetrafluoretileno expandido apresenta-se como uma opção factível para o tratamento das lesões iatrogênicas do ducto biliar, entretanto, deve ser utilizada com cautela, considerando o risco potencial de complicações.

Descritores: Ductos Biliares. Politetrafluoretileno. Próteses e Implantes. Cães. 


\section{Introduction}

The major cause of benign biliary lesions is surgical trauma. Laparoscopic biliary procedures, interventional endoscopic approaches and orthotopic liver transplantation surgeries have increased the number of reports of benign biliary strictures.

Bile duct injury brings about serious complications, and the outcome of the reparative surgery depends on the gravity of the injury intraoperative conditions and the technique $\operatorname{chosen}^{1-4}$.

Usually the diagnosis of extrahepatic biliary duct injury is delayed until clinical signs of obstruction have appeared. Immediate recognition and treatment of the injury are essential for a better outcome.

Because the biliary duct reconstruction is complex and does not have a high success rate, several techniques have been proposed. Biliary enteric anastomosis is, by far, the most common surgical procedure ${ }^{5,6}$ Biological tissues, such as veins, arteries, small bowel, omentum, gallbladder, fascial and muscular sheaths, skin, muscles and pericardium and other tissues have been utilized without reliable results ${ }^{7-16}$ On the other hand, synthetic grafts or prostheses developed in the last century, including Vitallium, rubber, Daflon, Silastic, expanded polytetrafluoroethylene (ePTFE), have been tested to improve the prognosis of surgical correction of iatrogenic lesions of the biliary tree $\mathrm{e}^{17-25}$ The variety of suggested techniques and materials shows that the results for the treatment of biliary duct damage are still unsatisfactory ${ }^{26}$ Growing evidence has supported the ePTFE tube, a Teflon-coated graft, in the management of common bile duct injury however, controversies about its use still remain.

Therefore, the aim of this study was to critically analyze the efficacy of this prosthesis as a surgical alternative in the treatment of bile duct injuries.

\section{Methods}

The present study was approved by the Ethics Committee for the Use of Laboratory Animals, Faculty of Medicine, Federal University of Rio de Janeiro. The principles outlined in the Council for International Organization of Medical Sciences (CIOMS) ethical code for animal experimentation and Brazilian laws were also followed.

Nineteen mongrel dogs weighing nearly $11 \mathrm{~kg}$ were randomly divided into 2 groups. The animals were anesthetized with $25 \mathrm{mg}$ of intravenous sodium thiopental $2.5 \%$ and $30 \mathrm{mg}$ of intramuscular ketamine. Each animal received one intramuscular benzylpenicillin (1 million units).
After sterile skin preparation a standard midline incision was made in dogs of both groups at the time of each intervention. Group $1(n=7)$ served as a sham and underwent 3 laparotomies with intervals of 30 days between them. The dogs underwent no other procedures.

Group $2(n=10)$ underwent 3 different operative procedures. (1) First one the common bile duct was tied with a double loop of $3 / 0$ prolene. (2) After 30 days, a second laparotomy was performed and the biliary occlusion was removed. A rectangular fragment $\left(0.5 \mathrm{~cm}^{2}\right)$ of the anterior wall was cut $2 \mathrm{~cm}$ above the transient ligature, and the resultant gap was covered with a patch of ePTFE fixed to the duct wall with a $6 / 0$ prolene suture (Figure 1). Following this procedure, a hepatic biopsy was performed. (3) After another 30-day period (60 days after the first surgery), a third and last laparotomy was performed. The animals were then sacrificed, and the liver, pancreas, extrahepatic bile ducts and duodenum were removed en bloc. The duodenum was opened and the gallbladder gently squeezed to observe for discharge of bile from the papilla. A percutaneous cholangiography was performed, and a small catheter was introduced into the biliary duct until it reached a segment proximal of the prosthesis site without resistance. For histopathological assessment, the samples were stained with Masson's trichrome and hematoxylin-eosin and observed with magnifications of $\mathrm{x} 100$ and $\mathrm{x} 400$.

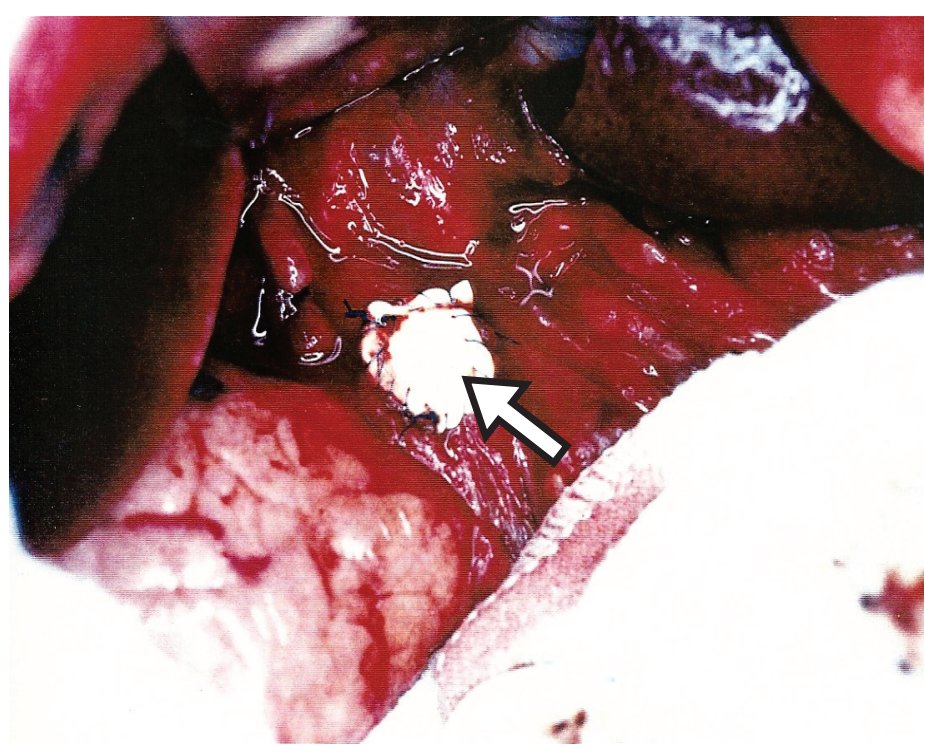

FIGURE 1 - A patch of ePTFE fixed to the duct wall of a Group 2 animal (arrow).

The average diameter of the common bile duct was measured with a ruler graded in centimetres in all animals of both groups.

The Wilcoxon non-parametric test was used to compare all 
data. Statistical significance was considered for $P$ values less than 0.05 .

\section{Results}

In Group 1(Control), the average common bile duct diameter was $0.49 \pm 0.11 \mathrm{~cm}$; in Group 2, at the first surgery, it was $0.49 \pm 0.09 \mathrm{~cm}$. In Group 2, the average of the biliary duct diameters at the second (day 30) and third laparotomy (day 60) laparotomies were respectively $1.62 \pm 0.53 \mathrm{~cm}$ (range 1.0-3.0 cm) and $1.33 \pm 0.78$ $\mathrm{cm}$ (range $0.6-3.0 \mathrm{~cm}$ ). The bile duct was dilated in the first surgery compared with the others surgeries $(P=0.002)$, but no significant difference was found between the results of the second and third surgical procedures $(P=0.10)$.

In Group 2, 30 days after the second surgical procedure, cholangiography confirmed total patency of the bile duct lumen in 7 animals and partial stricture in 3 others around the site at which the patch was placed (Figure 2). The permeability of the common bile duct was also tested by inserting a Nelaton catheter No.6 into the papilla, advancing it until it reached the segment proximal to the prosthetic implant. In all animals, even those with partial stricture, the catheter progressed smoothly in the bile duct. None of the animals showed jaundice, fever, dark urine, or light colored stools. There were also no signs of internal fistulas or peritoneal infection. In a preliminary cholangiographic study performed 30 days after bile duct ligation, a total cessation of progression of contrast was observed without recanalization (Figure 3).

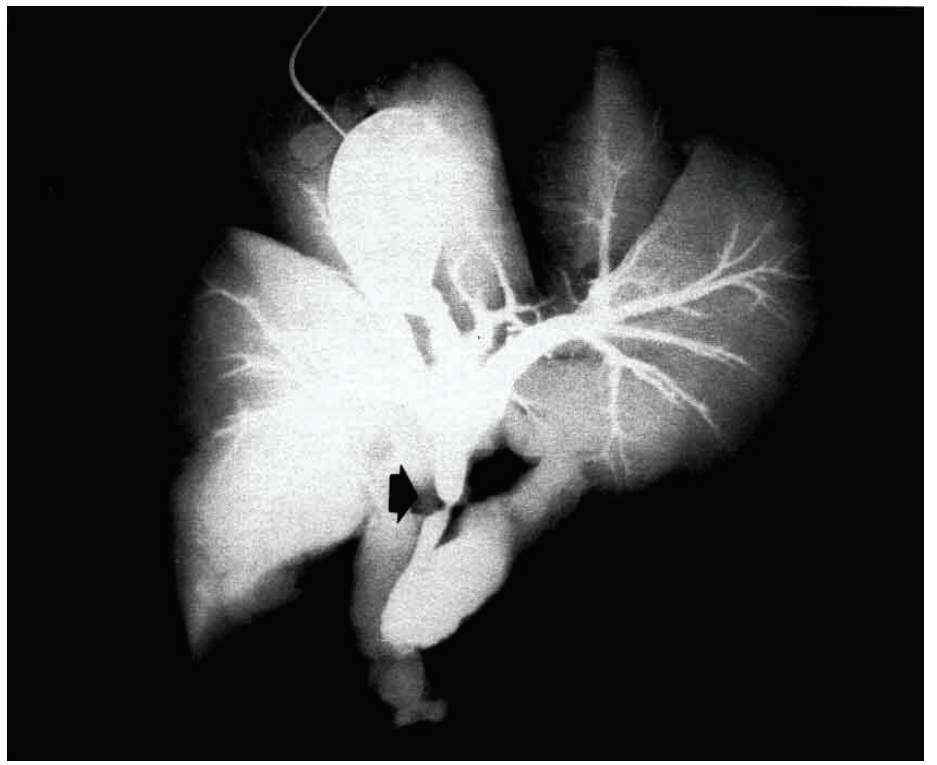

FIGURE 2 - Contrast material filling the duodenum and a small stricture (arrow) of the bile duct are seen.

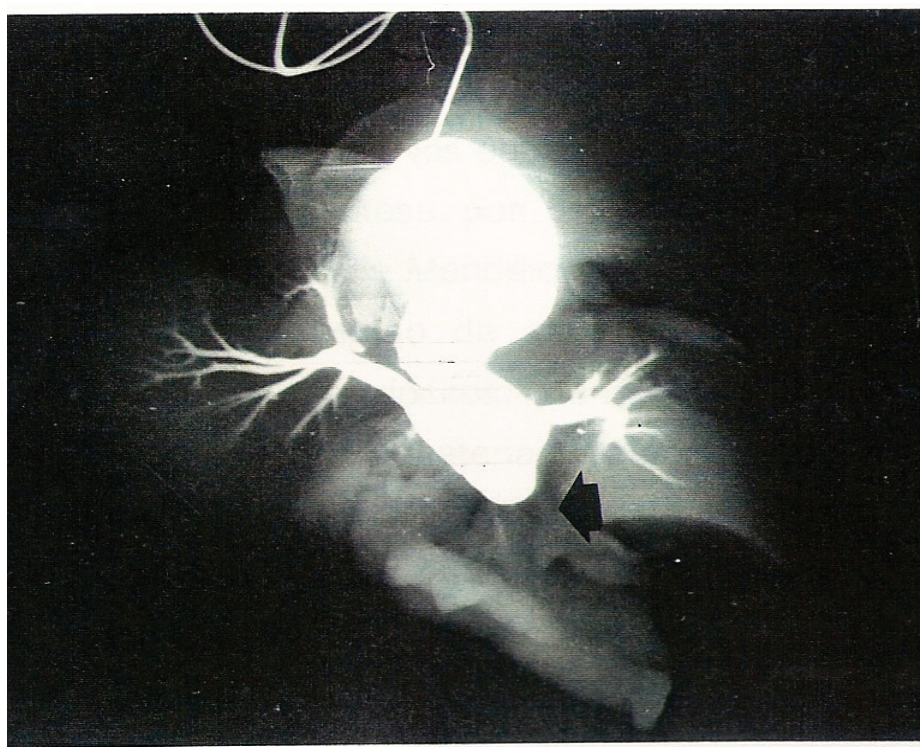

FIGURE 3 - Cholangiography revealed a pattern of complete biliary obstruction in the bile duct, still tied after 30 days.

In 4 animals of Group 2, the prosthesis was completely integrated into the common bile duct wall; in the remaining 6, however, it was partially free in the lumen of the common bile duct (Figure 4). There was no association between ductal dilatation and the presence of the prosthesis in the lumen.

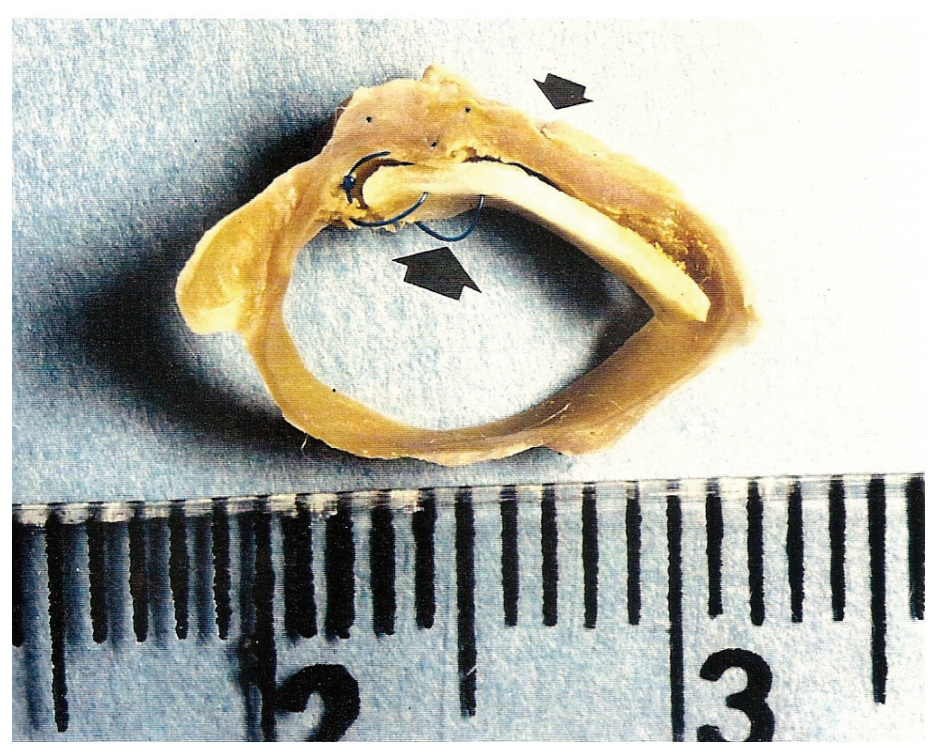

FIGURE 4 - A transverse slice of the common bile duct showing thickness (small arrow) and the prosthesis still tied at one of its ends by the prolene suture (large arrow).

At the end of the experiment, 60 days after the common bile duct obstruction, histopathological results of the hepatic biopsies of Group 2 displayed hepatocytes with a slightly edematous appearance 
and dense connective tissue recomposing the bile duct wall with a few inflammatory cells and hyperplasia particularly over the suture site. Moreover, 2 animals with stricture of the bile duct also had portal bile duct proliferation and focal necrosis that persisted until the end of the experiment. In 7 animals the epithelium was unable to cover the lumen of the prosthesis. In 3 animals hyperplastic epithelial cells were seen between the prosthesis and the layer of connective tissue that replaced the gap of the bile duct wall (Figure 5).

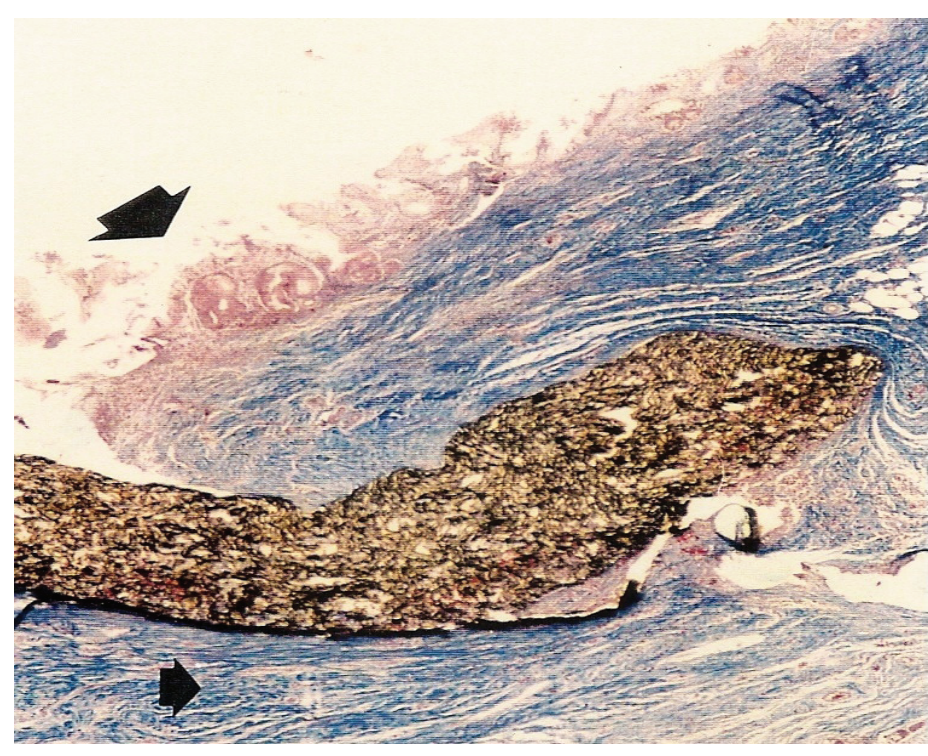

FIGURE 5 - Detail of the healing. Epithelial replacement of the duct wall by fibrosis (both arrows). The prosthesis was partially loosened into the lumen ( $x 40$, hematoxylin-eosin).

\section{Discussion}

Extrahepatic bile duct injury is most often caused by trauma, especially after cholecystectomy. Intraoperative occlusion by ligature, clip placement, laceration, transection, avulsion, thermal insult and excessive dissection, as well as by endoscopic procedures, are the principal mechanisms involved ${ }^{27}$

The management of iatrogenic injuries of the biliary tree is still a challenge. Bleeding, bile leakage, peritonitis, intra-abdominal infection, sepsis, fistulation and late manifestations such as stricture, recurrent cholangitis, and secondary biliary cirrhosis are some of the potential complications ${ }^{28}$

Segmental loss of ductal tissue or an extensive lateral defect may necessitate the use of prostheses or grafts to preserve the physiological passage of bile ${ }^{16}$ In the last century, new materials and prostheses have been developed and tested. The ePTFE prosthesis is a polymer of fluorine and carbon extruded under high pressure.
It creates a microporous material that has weaves of ePTFE fibrils interspersed with PTFE nodules. The internodal separation allows limited tissue ingrowth and contributes to stabilization of the implant. The surface of the prosthesis is both hydro- and homophobic but the perfusion of neither oxygen nor carbon dioxide is impaired. We chose a prosthesis with a $1 \mathrm{~mm}$ of thickness. It is easily shaped and may be sterilized. Because of its flexibility, surgical manipulation and anatomical adjustment are simple and easily performed. In addition to other conditions, ePTFE has been used for hernia repair, cardiovascular patching, vascular reconstruction, and soft tissue deficiencies.

In dogs, some hepatic ducts may join the biliary tree below the insertion of the cystic duct. Unlike in human anatomy, the canine true common bile duct is a segment a few centimeters long that runs between the last hepatic duct insertion and the duodenal wall ${ }^{29}$ To avoid clinical bias the patch reconstruction was performed at this site. The normal diameter of the common bile duct (Group 1) was approximately $0.5 \mathrm{~cm}$. A comparison between this diameter and those found after the second and third surgeries showed a significant difference $(P<0.002)$. All dogs in Group 2 showed dilatation of the extrahepatic bile duct, proximal to the ligature, before and after the reconstruction with ePTFE, but with a tendency toward biliary diameter reduction in 7 animals at the end of the experiment. These results are quite similar to those found by Carlson ${ }^{30}$. However, at the last laparotomy (day 60), 3 other animals in Group 2 had partial strictures with increased common bile duct diameters proximal to this compromised area.

Partial epithelialization of the inner surface of the prosthetic patch was observed in only 2 animals. In 1 animal the detachment of the synthetic material into the lumen allowed epithelial growth over the dense connective tissue, completely covering the gap injury in the bile duct wall. This was seen as an intense fibrotic tissue formation wrapping the prosthesis and reconstructing the duct wall. In 8 animals, however, the lumen surface under the ePTFE had no foreign body inflammatory reaction and there was no biliary salt nucleation, sludging or precipitation. Moreover analyses of the ePTFE in the reconstruction of the canine biliary system performed by Mendelowitz revealed an intense deposition of thick granulation tissue over the prosthesis with the presence of immature collagen, neovascularization and some bacterial deposition ${ }^{21}$

We recommended prophylactic antibiotics because of the bacterial contamination usually present in dogs in contrast to the human beings. Furthermore, bacterial adherence to the stent surfaces with partial blockage is the main complication after the use of biliary stents ${ }^{31}$

Focal necrosis in scattered cells within hepatic lobules and 
proliferation of duct epithelial cells that took place in 2 animals with strictures of the common bile duct were minor signs of cholestasis, but accumulation of bile pigment within the parenchyma was not seen. The slight edema of hepatocytes in the other 7 animals of Group 2 showed limited damage without severity. Virtually all of these parameters, with the exception of the necrosis in the 2 aforementioned animals, normalized at the end of the experiment.

Despite the sporadic success of the treatment of iatrogenic biliary tree injury using ePTFE, the possibility of a high incidence of free inorganic material in the lumen of the bile duct is noteworthy ${ }^{21}$. If detachment from biliary wall is partial, it may not only interfere with bile flow and thus promote gallstone formation, but also create pathologic conditions (stasis and foreign body) that predispose to infection. If detachment is complete, the loose prosthetic graft may cause a papillary obstruction within the lumen. Moreover, the retrieval of a partially unfastened prosthesis still fixed to the ductal wall would necessitate removal of the suture in a complex reoperative procedure, which would require accessing an extrahepatic bile duct that is surrounded by extensive chronic fibrosis.

The choice of currently available surgical approaches is still controversial because the likelihood of a long-term outcome free of symptoms is not yet apparent. Considering that biliary reconstruction should be personalized based on the extent, type, and level of injury, as well as on the clinical status of the patient and the expertise of the surgical team, a careful approach is imperative.

\section{Conclusions}

Although ePTFE may be helpful in some perioperative circumstances, surgeons must be familiar with the frequent risk of significant morbidity that could result not only from a foreign body partially or totally free in the biliary duct lumen, but also from segmental stricture of the biliary tree. The establishment of an adequate strategy for biliary duct reconstruction with ePTFE requires further studies with long-term follow-ups.

\section{References}

1. Moossa AR, Mayer, AD, Stabile B. Iatrogenic injury to the bile duct. Who, how, where? Arch Surg. 1990;125:1028-30.

2. Schultz F, Függer R, Herbest F, Hul I. The therapy of iatrogenic lesions of the bile duct. Hepatogastroenterology. 1990;37:149-55.

3. Rossi RL, Tsao JI. Biliary reconstruction. Surg Clin North Am. 1994;74:825-41.

4. Gomez NA, Alvarez LR, Mite A, Andrade JP, Alvarez JR, Vargas PE, Tomala NE, Vivas AF, Zapatier JA. Repair of bile duct injuries with gore-tex vascular grafts: experimental study in dogs. J Gastrointest Surg. 2002;6:116-20.
5. Innes JT, Ferrara JJ, Carey LC. Biliary reconstruction without transanastomotic stent. Am Surg. 1988;54:27-30.

6. Besozzi A, Selvaggiuolo, M Mitaritonno M. Non-iatrogenic common bile duct injury repair by Gore-Tex vascular graft: a case report. Chir Ital. 2004;56:261-4.

7. Hardin CA, Kittle CF. The experimental use of free arterial and splitthickness skin grafts for bridging defects in the common bile ducts of the dog. Surgery. 1951;30:834-40.

8. Santos M, Smith ML, Hughes CW, Rilley PA. Reconstruction of the bile ducts. An experimental study using free arterial grafts and nylon mesh tubes. Surgery. 1957;42:462-73.

9. Pena LI, Husni EA. A comparative study of autogenous vein and dacron patch grafts in the dog. Arch Surg. 1968;96:369-72.

10. Sandblom P, Tabrizian M, Rigo M, Fluckiger A. Repair of common bile duct defects using the gallbladder or cystic duct as a pedicled graft. Surg Gynecol Obstet. 1975;140:425-32.

11. Rutledge RH. Methods of repair of noncircumferential bile duct defects. Surgery. 1983;93:333-42.

12. Bottger T, Mann B, Pickel B, Weber W, Sorger K, Junginger T. Pedicle graft of small bowel as a partial replacement of the extrahepatic bile duct. Langenbecks Arch Chir. 1991;376:77-84.

13. Lexer GW, Zukriekel M, Meiser G, Kaindl H, Waclawiczek HW, Pimpl W, Boeckl O. Human pericardial patch in the treatment of iatrogenic common bile duct stenosis. An experimental study in pigs. Wien Klin Wochenschr. 1992;104:456-60.

14. Flati G, Flati D, Porowsaka B, Rossi G.; Francavilla S, Santoro E, Carboni M. Circumferential choledochoplasties with autologous venous and arterial grafts. Microsurgery. 1993;14, 628-33.

15. Capitanich P, Herrera J, Iovaldi ML, Balbuena R, Casas G, Malizia P, Bun M, Mezzadri N. Bile duct replacement using an autologous femoral vein graft: an experimental study. Preliminary results. J Gastrointest Surg. 2005;9:369-73.

16. Heistermann HP, Palmes D, Stratmann U, Hohlbach G, Hierlemann $\mathrm{H}$, Langer M, Spiegel HU. A new technique for reconstruction of the common bile duct by an autologous vein graft and a biodegradable endoluminal stent. J Invest Surg. 2006;19:57-60.

17. Pearse HE. Vitallium tubes in biliary surgery. Ann. Surg. 1942;115:1031-42.

18. Hallberg D, Johnson G. Teflon use in choledochoplasty in the dog. Acta Chir Scand. 1960;119:120-2.

19. Thomas JP, Metropol HJ, Meyers RT. Teflon patch graft for reconstruction of the extrahepatic bile ducts. Ann Surg. 1964;160:96770.

20. Bradley LE. An evaluation of rubber tube with silicone as choledochal replacement. Am J Surg. 1967;113:501-6.

21. Mendelowitz DS, Beal, JM. Expanded polytetrafluoroethylene in reconstruction of the canine biliary system. Am J Surg. 1982;143:2214.

22. Sezeur A, Kracht M, Rey, P, Leandri J, Malafosse M. Loss of substance in bile ducts treated by a new surgical endoprothesis. Br J Surg. 1987;74:731-3.

23. Schein M, Assalia A, Hashimonai M. Vascular prosthetic bypass grafting in obstructive jaundice. Int Surg. 1994;79:65-7.

24. Christensen M, Laursen HB, Rokkjaer M, Jensen PF, Yasuda Y, Mortensen F. Reconstruction of the common bile duct by a vascular prosthetic graft: an experimental study in pigs. J Hepatobiliary Pancreat Surg. 2005;12:231-4.

25. Aikawa M, Miyazawa M, Okamoto K, Toshimitsu Y, Torii T, Okada K, Akimoto N, Ohtani Y, Koyama I, Yoshito I. A novel treatment for bile duct injury with a tissue-engineered bioabsorbable polymer patch. Surgery. 2010;147:575-80.

26. Zografakis JG, Jones BT, Ravichardran, Evancho-Chapman MM, Schmidt SP, Arends D, Funk KM, Gingras P. Endoluminal 
reconstruction of the canine common biliary duct. Curr Surg. 2003;60:437-41.

27. Martin RF, Rossi RL. Bile duct injuries: spectrum, mechanisms of injury, and their prevention. Surg Clin North Am. 1994;74:781-804.

28. Mutter D, Aprahamian M, Evrard S, Damgé C, Marescaux J. Biomaterials for primary closure of a choledochotomy in dogs. Eur Surg Res. 1996;28:32-8.

29. Imagawa T, Ueno T, Tsuka T, Okamoto Y, Minami S. Anatomical variations of the extrahepatic ducts in dogs: knowledge for surgical procedures. J Vet Med Sci. 2010;72:339-41.
30. Carlson E, Zurovski CF, Campbell, Chvapil M. Morphologic, biophysical and biochemical consequences of ligation of the common biliary duct in the dog. Am J Pathol. 1977;86:301-20.

31. Yu JL, Andersson R, Parsson H, Hallberg E, Ljungh A, Bengmark S. A bacteriologic and scanning electron microscope study after implantation of foreign bodies in the biliary tract in rats. Scand J Gastroenterol. 1996;31:175-81.

\section{Correspondence:}

Alberto Schanaider

Ilha do Fundão, Cidade Universitária, UFRJ

Centro de Cirurgia Experimental

Av. Carlos Chagas Filho, 372/Bloco J, $2^{\circ}$ andar

21941-902 Rio de Janeiro - RJ Brasil

Tel: (55 21)2562-6549

alberto-sch@ig.com.br
Conflict of interest: none Financial source: none

Received: December 10, 2010

Review: February 14, 2011

Accepted: March 15, 2011 